\title{
Decalcification mechanism of concrete by organic matters in atmosphere
}

\author{
Takashi Tomoto and Akihiro Moriyoshi
}

\begin{abstract}
This study confirmed that concrete structures and historical structures made of limestone absorb environmental endocrine disrupters such as anion surfactant and phthalic acid esters contained in windshield washer fluid by using ${ }^{1} \mathrm{H}$ nuclear magnetic resonance (NMR), high-performance liquid chromatography (HPLC), gas chromatograph mass spectrometer (GC-MS), and other analytical techniques. Furthermore, it was confirmed that environmental endocrine disrupting organic matter, including phthalic acid esters, penetrated into concrete and accelerated its deterioration and that calcium salt of phthalic acid esters existed in decalcified concrete by means of solid-state cross polarization magic angle spinning carbon13 (CPMAS ${ }^{13} \mathrm{C}$ ) NMR and electron probe microanalysis (EPMA). This phenomenon was demonstrated in a laboratory experiment. Bone mineral content (BMC) and a specific surface area of decalcified concrete slabs were measured in each layer in the depth direction, and it was revealed that deterioration was more severe and cement paste was more porous in the layers closer to the slab surface.
\end{abstract}

Key words: cement, concrete, decalcification, organic matter, aspiration, nuclear magnetic resonance (NMR), highperformance liquid chromatography (HPLC), gas chromatograph mass spectrometer (GC-MS), electron probe microanalysis (EPMA).

Résumé : Cette étude a confirmé que les structures en béton de ciment et les structures historiques fabriquées de calcaire absorbent des perturbateurs endocriniens environnementaux, tels que les surfactants anioniques et les esters d'acide phtalique contenus dans les liquides lave-glaces; on a utilisé la résonance magnétique nucléaire (RMN) ${ }^{1} \mathrm{H}$, la chromatographie liquide à haute performance (CLHP), la chromatographie en phase gazeuse et spectrométrie de masse ( «GC-MS »), ainsi que d'autres techniques analytiques. De plus, il a été confirmé que les matières organiques des perturbateurs endocriniens environnementaux, incluant les esters d'acide phtalique, pénétraient dans le béton de ciment et accéléraient sa détérioration et que le sel de calcium des esters d'acide phtalique était présent dans le béton de ciment décalcifié; la méthode utilisée était le CPMAS ${ }^{13} \mathrm{C}$, la RMN et le microanalyseur à sonde électronique («EPMA »). Ce phénomène a été démontré lors d'une étude en laboratoire. Le contenu minéral osseux («BMC») ainsi que la surface spécifique des dalles de béton de ciment décalcifiées ont été mesurés à chaque couche dans la direction de l'épaisseur; il s'est avéré que la détérioration était plus grave et que la pâte de ciment était plus poreuse dans les couches près de la surface de la dalle.

Mots-clés : béton de ciment, décalcification, matière organique, aspiration, résonance magnétique nucléaire (RMN), chromatographie liquide à haute performance (CLHP), chromatographie en phase gazeuse et spectrométrie de masse (« GC-MS »), microanalyseur à sonde électronique (« EPMA »).

[Traduit par la Rédaction]

\section{Introduction}

Conventionally, concrete structures were considered to be semi-permanent structures. However, the service life of concrete has recently decreased; in some cases, 30 -year old concrete structures have been decalcified as deep as $15 \mathrm{~cm}$ below the surface. Since it is believed that carbon dioxide in the atmosphere decalcifies concrete up to 5-20 mm below the surface in 20 years (Kishitani et al. 1990), decalcification of concrete actually progresses very quickly. Generally, decalcification caused by carbon dioxide, freezing damage,

Received 8 September 2007. Revision accepted 6 March 2008. Published on the NRC Research Press Web site at cjce.nrc.ca on 11 July 2008.

T. Tomoto ${ }^{1,2}$ and A. Moriyoshi. ${ }^{3}$ Division of Urban and Environmental Engineering, Graduate School of Engineering, Hokkaido University, North 13 West 8, Kita-ku, Sapporo 060-8628, Japan.

Written discussion of this technical note is welcomed and will be received by the Editor until 30 November 2008.

${ }^{1}$ Corresponding author (e-mail: tomoto@obayashi-road.co.jp).

${ }^{2}$ Present address: Technical Research Institute, Obayashi Road Corporation, 4-640 Shimokiyoto, Kiyose, Tokyo 204-0011, Japan.

${ }^{3}$ Present address: Material Science Laboratory, Hokkaido University, 2-1-9-10 Kiyota, Kiyota-ku, Sapporo 004-0842, Japan. 
salt damage, and alkali-aggregate reaction was recognized as a factor causing concrete to deteriorate. However, one of the authors published a report regarding deterioration (decalcification) of concrete caused by anion surfactant, as organic matter in windshield washer fluid (Moriyoshi et al. 2002). According to this report, anion surfactant (or one of the salt compounds in the organic matter) chemical reacting with the calcium ions in concrete causes decalcification of the concrete and reduces its weight in a short period of time, leading to a condition similar to "osteoporosis" in humans, and not only decalcification but also strength degradation deep inside the concrete is observed. This report also confirmed the presence of large amounts of black organic matter (12 $\mathrm{kg}$ per $1 \mathrm{~m}^{3}$ of concrete), not including additives or surfactant, in decalcified concrete actually used in a civil engineering structure.

Meanwhile, there have been reports that asphalt mixtures and concrete are subject to a phenomenon similar to "aspiration", as seen in plants and animals, with changes in ambient temperature (Reinhardt 1997; Sasaki et al. 2006a, $2006 b, 2006 c$ ). These reports illustrate how, under certain climatic conditions and as temperatures change, moisture contained in the air easily penetrates even civil engineering structures that are impermeable to water in the form of liquid. Condensation then builds up and forms water deep inside the structures and, as a result, a large amount of water accumulates in civil engineering structures in a short period of time. It is therefore highly likely that the aforementioned organic matter found in concrete exposed to indoor or outdoor environments has been absorbed from the atmosphere through a process of "aspiration" by the concrete. It is suspected that the same phenomenon occurs in every civil engineering structure around the world and it accelerates the deterioration of concrete.

Historical structures made of limestone have been damaged by acid rain all over the world (Baer and Snethlage 1996). We believe that anion surfactant decalcifies historical limestone structures.

Taking these considerations into account, this study identifies various types of organic matter in the air that deteriorate concrete and limestone and determines the causes of deterioration.

\section{Experiment}

\section{Confirmation of the presence of organic matter in historical structures made of limestone}

The authors reported that the deterioration of concrete used in civil engineering structures throughout Japan is accelerated by organic matter including anion surfactant (Moriyoshi et al. 2002). Such decalcification caused by anion surfactant is also suspected to occur in historical structures made of limestone. An experiment was conducted to confirm the presence of organic matter in a historical structure made of limestone in France.

\section{Samples}

\section{Decalcified lime}

Samples collected from the inside of two types of limestone used in a historical structure in Lyon, France, were powdered and organic matter was extracted with methanol using a Soxhlet extractor. After samples were extracted with methanol, additional samples were extracted with chloroform, and then the extracted organic matter was analyzed with the ${ }^{1} \mathrm{H}$ nuclear magnetic resonance (NMR) method.

\section{Analytical method}

\section{${ }^{1} \mathrm{H}$ nuclear magnetic resonance}

Components extracted by chloroform were characterized using the ${ }^{1} \mathrm{H}$ NMR method on a JOELEX 400 using $\mathrm{CDCl}_{3}$ solution with tetramethylsilene (TMS) as a standard signal.

\section{Identification of organic matter in decalcified concrete}

The authors have confirmed the presence of black organic matter, which does not include anion surfactant, in decalcified concrete used in civil engineering structures throughout Japan (Moriyoshi et al. 2002). Therefore, the black organic matter has been identified and the effect of the black organic matter on concrete will be discussed.

\section{Sample}

\section{Decalcified concrete}

Samples of decalcified concrete were collected from the center lane of an express highway in Osaka with a traffic volume of approximately 40000 vehicles/day/lane. The highway was constructed 30 years ago. The specimens of the highway concrete were sprayed with phenolphthalein liquid, but they were not tinted pink. This means that $\mathrm{pH}$ of the concrete specimen decreased from 12 to 10 or smaller (decalcification of concrete). Samples of decalcified concrete were milled into powder finer than $0.074 \mathrm{~mm}$ in grain size.

\section{Analytical method}

\section{High-performance liquid chromatography}

Samples of decalcified concrete for high-performance liquid chromatography (HPLC) testing, which were dissolved with benzene methanol solution (ratio of volume: $1: 1$ ) to obtain soluble components, were dissolved again with normal hexane to obtain soluble compounds (Yokoyama et al. 1987). The samples (oil components) obtained after the latter extractions were divided into saturated hydrocarbon, monocyclic compounds, bicyclic compounds, and polycyclic compounds using a HPLC (Nippon Bunkou, TRI-Rotor with ZORBAX-BP-NH2, column with inner diameter $10 \mathrm{~mm}$, length $250 \mathrm{~mm}$, speed of chloroform of solution: $5.0 \mathrm{~mL} / \mathrm{min}$.) (Moriyoshi et al. 2002). Each compound, except the polar compound, was gathered by the aid of RI and UV detectors. The polar compound was collected by chloroform.

\section{Gas chromatograph mass spectrometer}

To examine the polar component of decalcified concrete separated by HPLC, organic matter was identified by gas chromatograph mass spectrometer (GC-MS) (JMS-AX-500, column with inner diameter $0.32 \mathrm{~mm}$, length $30 \mathrm{~m}$, column temperature: $50-280{ }^{\circ} \mathrm{C}$ ).

\section{CPMAS ${ }^{13} \mathrm{C}$ nuclear magnetic resonance}

By analyzing powdered decalcified concrete, as it is, by CPMAS ${ }^{13} \mathrm{C}$ NMR (BRUKER MSL300; resonance fre- 
quency: $75.47 \mathrm{MHz}$; spin rate: $10 \mathrm{kHz}$; pulse width: $4.5 \mu \mathrm{s}$ for the $90^{\circ}$ pulse; contact time: $1 \mathrm{~ms}$; acquisition time: $30 \mathrm{~ms}$; recycle delay: $5 \mathrm{~s}$; number of scans: 20000 ), calcium salt of phthalic acid esters existing in decalcified concrete was identified.

\section{Electron probe microanalysis}

Electron probe microanalysis (EPMA) (JEOL JXA-8900) was carried out to analyze calcium salt of phthalic acid ester in thin layered $(30-40 \mu \mathrm{m})$ samples of decalcified concrete at ambient temperature. Samples were covered with carbon. Both mapping analysis of oxygen $(\mathrm{O})$ and calcium $(\mathrm{Ca})$ were conducted.

\section{Measurement of the bone mineral content of decalcified concrete slabs}

Calcium is a mineral and a major component of human bones and is also a major component of concrete. When calcium intake is insufficient, bones begin to decalcify to maintain their blood calcium level. If this condition continues, bone calcium content decreases, developing osteoporosis. In typical medical settings, bone mineral content (BMC) is measured in diagnosing osteoporosis. Decalcification of decalcified concrete causes calcium to leak out. Accordingly, BMC of decalcified concrete was measured with a bone mineral analyzer used in medical settings. It is presumed that elution of calcium content from concrete results in an increase in specific surface area of the concrete. For this reason, a specific surface area of decalcified concrete was measured using the Brunauer, Emmett, and Teller (BET) method for a comparison with BMC. In addition, organic matter was extracted from each layer to determine the organic matter content and conduct ${ }^{1} \mathrm{H}$ NMR analysis.

\section{Sample}

\section{Decalcified concrete}

A slab of concrete from a 46-year-old bridge (concrete slab: thickness: $30 \mathrm{~cm}$, covered with $8 \mathrm{~cm}$ thick two layer asphalt pavement; decalcification depth: $30 \mathrm{~cm}$ from the surface to the slab bottom) was collected (diameter: $10 \mathrm{~cm}$ ) using a core cutter, and samples were cut out every $3 \mathrm{~cm}$ in the depth direction. These samples were subjected to diametral compression tests. The crushed samples were further crushed into particles of $0.074 \mathrm{~mm}$ or less and the sand and crushed stones were removed (samples are now mostly cement paste). Then, these samples underwent methanol extraction using a Soxhlet extractor and then chloroform extraction. The organic matter content of the cement paste was determined and the organic matter after chloroform extraction was analyzed using the ${ }^{1} \mathrm{H}$ NMR method. Measurements for BMC and specific surface areas were made on the finely crushed samples before extraction.

\section{Analytical method}

\section{Bone mineral content}

Bone mineral content was measured using a device (Hologic QDR-4500) generally used in medical settings by means of the dual energy X-ray absorptiometry (DXA method). The DXA method is a means to measure BMC based on the rate at which soft tissue and bone tissue absorb two X-ray beams with different energy levels. With this device, BMC of powdered decalcified concrete was determined.

\section{Measurement of specific surface area of samples}

Specific surface areas of decalcified concrete were measured using the BET method (Shimadzu- Micromeritics Gemini2370), which is a general method for measuring particulate specific surface areas. The BET method is a technique to find specific surface areas in terms of the relationship between pressure and the amount of adsorption when gas molecules, whose size is known, are adsorbed by solid surfaces.

\section{Results and discussions}

\section{Organic matter in historical structures made of limestone}

${ }^{1} \mathrm{H}$ NMR spectra of organic matter extracted from decalcified lime are illustrated in Fig. 1. In the figure, $(a)$ and (b) show ${ }^{1} \mathrm{H}$ NMR spectra of organic matter extracted from two types of decalcified lime, while $(c)$ shows that of phthalic acid esters (Di-n-butyl phthalate, DBP). The peak of $(a)$ and $(b)$ in the figure around $3.6 \mathrm{ppm}$ indicates a peak in the oxyethylene group - $\left(\mathrm{O}-\mathrm{CH}_{2} \mathrm{CH}_{2}\right)_{n^{-}}$(Moriyoshi et al. 2002). Accordingly, the presence of anion surfactant contained in windshield washer fluid is also confirmed in decalcified lime and it is expected that limestone is decalcified and decalcified because of anion surfactant in windshield washer fluid (Moriyoshi et al. 2002). The peaks around 7.57.7.7 ppm and $4.3 \mathrm{ppm}$ indicate the peak specific to phthalic acid esters; the former is a peak in the benzene ring and the latter is that of $-\mathrm{COO}-\mathrm{CH}_{2}$. The peaks around $0.9,1.2$, and $1.6 \mathrm{ppm}$ are believed to be the peaks in the alkyl group of phthalic acid esters. Based on these findings, the presence of organic matter including anion surfactant and phthalic acid esters in windshield washer fluid was confirmed.

\section{Identification of organic matter in decalcified concrete}

Results of GC-MS identification of polar component separated from organic matter in decalcified concrete by HPLC are shown in Table 1. As shown in Table 1, phthalic acid esters including di-n-butyl phthalate (DBP), di- (2-ethylhexyl) phthalate (DEHP) and di-octyl phthalate (DOP), amides including palmitoleamide $\left(\mathrm{C}_{15} \mathrm{H}_{29} \mathrm{CONH}_{2}\right)$, palmitamide $\left(\mathrm{C}_{15} \mathrm{H}_{31} \mathrm{CONH}_{2}\right)$, oleamide $\left(\mathrm{C}_{17} \mathrm{H}_{33} \mathrm{CONH}_{2}\right)$ and stearamide $\left(\mathrm{C}_{17} \mathrm{H}_{35} \mathrm{CONH}_{2}\right)$, octadecane, 2,2,4-trimethyl-1 and 3pentanediol diisobutylate (TMPDIB) were detected from decalcified concrete. In Japan, DBP, DEHP and other phthalic acid esters are designated as specific substances that are suspected to have endocrine disrupting effects (Ministry of Economy, Trade and Industry Government of Japan 2002).

\section{Mechanisms that cause deterioration}

The presence of a variety of organic matter in the air was confirmed in decalcified concrete as well as limestone. Organic matter in such structures was absorbed from the atmosphere through a process of "aspiration." In general, one-third of chemical components that comprise concrete is calcium hydroxide. Calcium hydroxide determines the $\mathrm{pH}$ of the entire concrete structure and $\mathrm{pH}$ of healthy concrete is 
Fig. 1. The ${ }^{1} \mathrm{H}$ NMR spectra of organic matter extracted from $(a)$ and $(b)$ decalcified lime and $(c)$ phthalic acid ester.

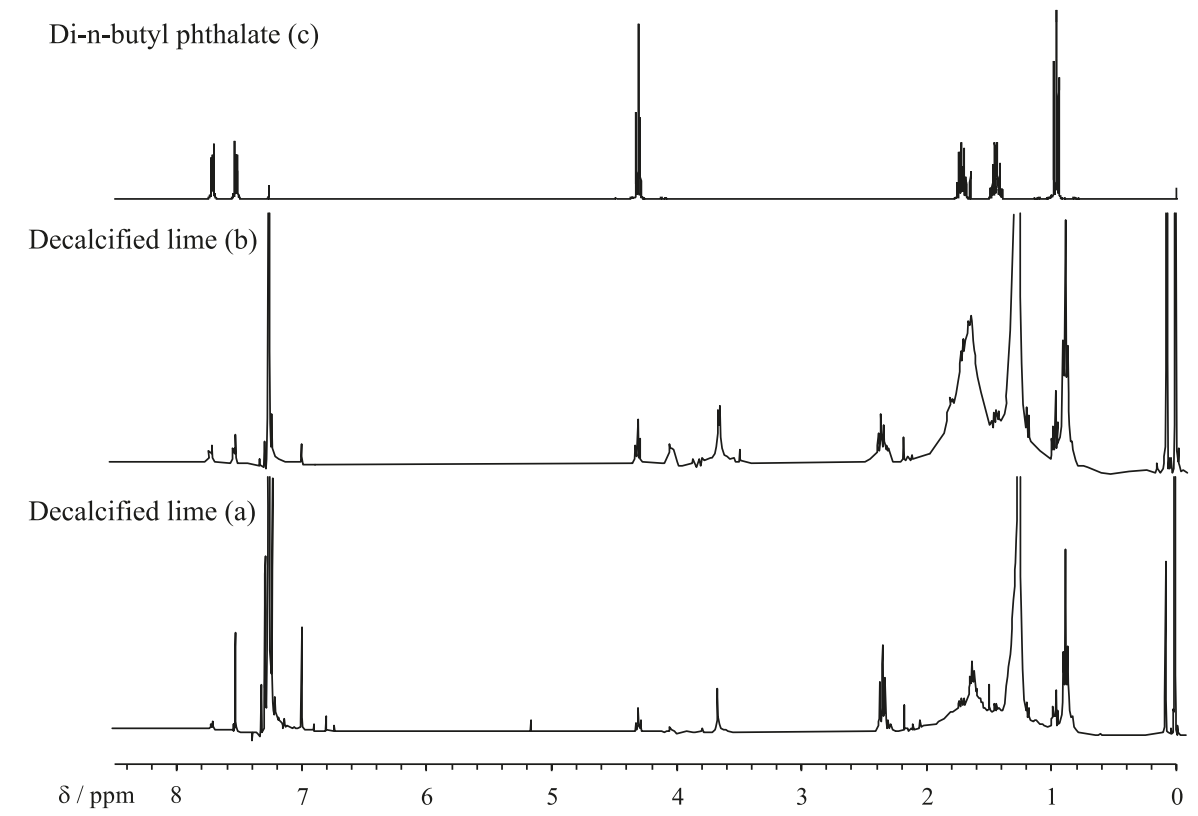

Table 1. Main chemical components of polar compound in decalcified concrete.

\begin{tabular}{lll}
\hline Phthalic acid ester & $\mathrm{R}_{1}{ }^{(5)} \mathrm{CONH}_{2}$ (Amide) & Normal paraffin \\
\hline $\mathrm{DBP}^{(1)}, \mathrm{DEHP}^{(2)}, \mathrm{DOP}^{(3)}, \mathrm{TMPDIB}^{(4)}$ & $\mathrm{C}_{15} \mathrm{H}_{29}, \mathrm{C}_{15} \mathrm{H}_{31}, \mathrm{C}_{17} \mathrm{H}_{33}, \mathrm{C}_{17} \mathrm{H}_{35}$ & $\mathrm{C}_{18} \mathrm{H}_{38}$ \\
\hline
\end{tabular}

Note: ${ }^{(1)}$ DBP: di-n-butyl phthalate; ${ }^{(2)}$ DEHP: di-2(ethylhexyl) phthalate; ${ }^{(3)}$ DOP: di-octyl phthalate; ${ }^{(4)}$ TMPDIB: 2,2,4-trimethyl-1,3-pentanediol diisobutylate; ${ }^{(5)} \mathrm{R}_{1}$ : alkyl moiety.

generally between 12 and 13 . The decalcification of concrete due to carbon dioxide is caused by the reaction of calcium hydroxide with carbon dioxide to generate calcium carbonate. When phthalic acid esters penetrate into strong alkaline substances such as concrete, ester hydrolysis is expected to occur inside the substances. The expected reaction between phthalic acid esters and calcium hydroxide in concrete is expressed in the following equation:<smiles>[R2]OC(=O)c1ccccc1C(=O)O[R2]</smiles>

where alkyl moiety: $\mathrm{R}_{2}=\mathrm{C}_{4} \mathrm{H}_{9}$ (for DBP), $\mathrm{C}_{8} \mathrm{H}_{17}$ (for DOP, DEHP)

Thus, decalcification of concrete is caused by the reaction of phthalic acid esters and calcium hydroxide in concrete, during which calcium salt of phthalic acid esters and alcohol are generated. To verify this reaction, the presence of calcium salt of phthalic acid esters in decalcified concrete was confirmed by CPMAS ${ }^{13} \mathrm{C}$ NMR analysis and EPMA. CPMAS ${ }^{13} \mathrm{C}$ NMR spectra of powdered decalcified concrete are shown in Fig. 2. Figures $2 a, 2 b$, and $2 c$ show the spectra of phthalate calcium reagent as the standard, decalcified concrete, and fresh concrete for comparison (water/cement = 41\%; slump: $13 \mathrm{~cm}$; cement: $18.8 \%$; crushed stone: $43 \%$; sand: $31.1 \%$; Portland cement), respectively. The peaks of the spectrum of phthalate calcium (Fig. $2 a$ ) at 180 ppm indi- cate double bond-C=OO-carbon and at 120-150 ppm benzene ring carbon. The figure reveals that such peaks cannot be seen in the spectrum of fresh concrete (Fig. 2c); however a double bond-C=OO-peak around $180 \mathrm{ppm}$ and benzene ring peak around $120-150 \mathrm{ppm}$ are found in the spectrum of decalcified concrete (Fig. $2 b$ ), which are very similar to the peaks of phthalate calcium as the standard (Fig. 2a).

An EPMA was carried out to analyze calcium salt of phthalic acid ester in thin layered samples of decalcified concrete at ambient temperature. Both mapping analysis of oxygen $(\mathrm{O})$ and calcium $(\mathrm{Ca})$ were conducted for carbon covered sample at $100 \mu \mathrm{m}^{2}$. Ratio $(\mathrm{O}: \mathrm{Ca}=41.5 / 16: 25.1 / 40=$ $4.1: 1)$ of oxygen $(\mathrm{O}: 41.5 \%)$ and calcium constituent $(\mathrm{Ca}$ : $25.1 \%$ ) in micro point at $100 \mu \mathrm{m}^{2}$ were calculated. As the test results, the ratio of four for several micro points (about 
Fig. 2. The CPMAS ${ }^{13} \mathrm{C}$ NMR spectrum calcium salt of $(a)$ phthalic acid ester, $(b)$ decalcified concrete, and $(c)$ fresh concrete.

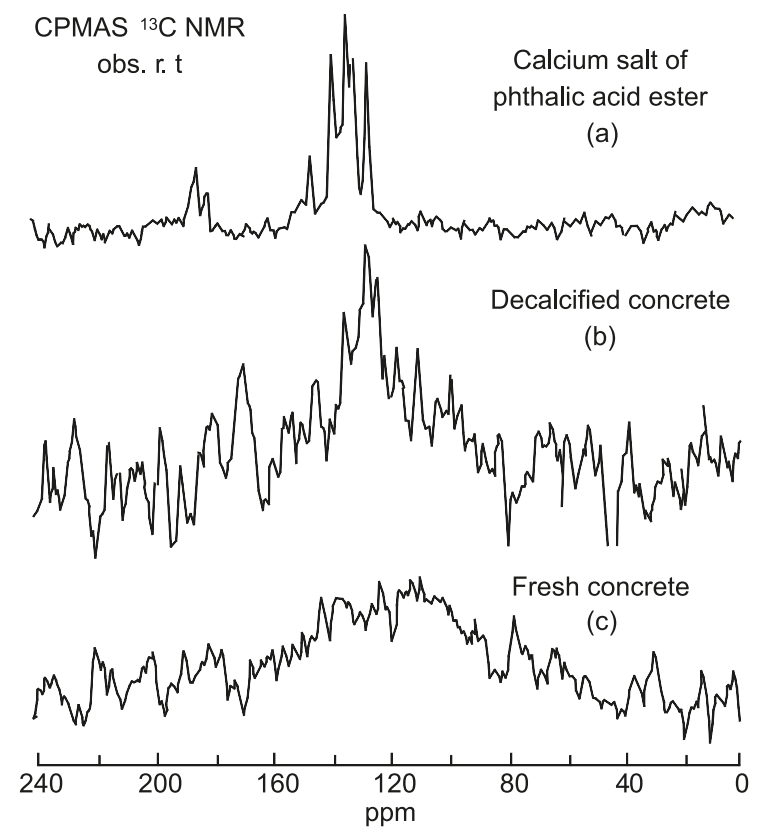

10 micron) was obtained. This value is the same as the ratio (four) of calcium salt of phthalic acid ester $\left(\mathrm{C}_{6} \mathrm{H}_{4}(\mathrm{COO})_{2} \mathrm{Ca}, \mathrm{O}: \mathrm{Ca}=4: 1\right)$.

Accordingly, the presence of calcium salt of phthalic acid esters in decalcified concrete was confirmed based on the results of these CPMAS ${ }^{13} \mathrm{C}$ NMR and EPMA analyses. It was also confirmed that chemical reaction occurs between phthalic acid esters and calcium ions inside concrete.

Furthermore, if DEHP or DBP or DOP (each 0.05 g, 10 $000 \mathrm{ppm}$ ) was added to the powdered sample of fresh cement paste $(5 \mathrm{~g})$ at ambient temperature, respectively, 2ethyl-1-hexanol or butanol or octanol, which was generated with a stroke of the pen from DEHP or DBP or DOP, respectively, was also found in the mixture using GC-MS.

These results confirmed that phthalic acid esters, as specific substances that have endocrine disrupting effects, not only had adverse effects on humans but also caused other damage on concrete by decalcifying it in a short period of time.

\section{Tensile strength, specific surface area and bone mineral content of decalcified concrete slabs}

Figure 3 indicates the concentration (weight \%) of organic matter extracted from a slab of decalcified concrete in the cement paste in each layer, Fig. 4 displays the tensile strength for each layer, Fig. 5 the specific surface area of cement paste for each layer, and Fig. 6 the BMC of cement paste for each layer. The layer number " 1 " in the figures corresponds to the top layer of the slab, and the larger the number the deeper the layer lies. Based on Fig. 3, it was found that organic matter concentration is approximately 0.02 to $0.035 \%$ and the concentration is slightly larger in lower layers. Figure 4 demonstrates that tensile strength increases as the concrete slab depth increases, while Fig. 5 demonstrates that specific surface areas increase as the layer is closer to the surface and it decreases as the layer lies
Fig. 3. Organic matter concentration for each layer of decalcified concrete slab.

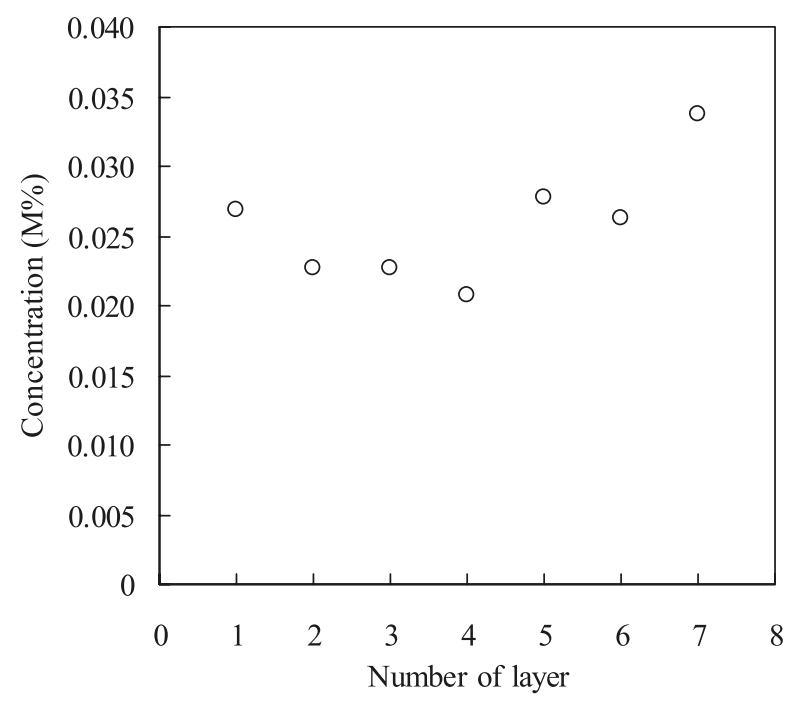

Fig. 4. Tensile strength for each layer of decalcified concrete slab.

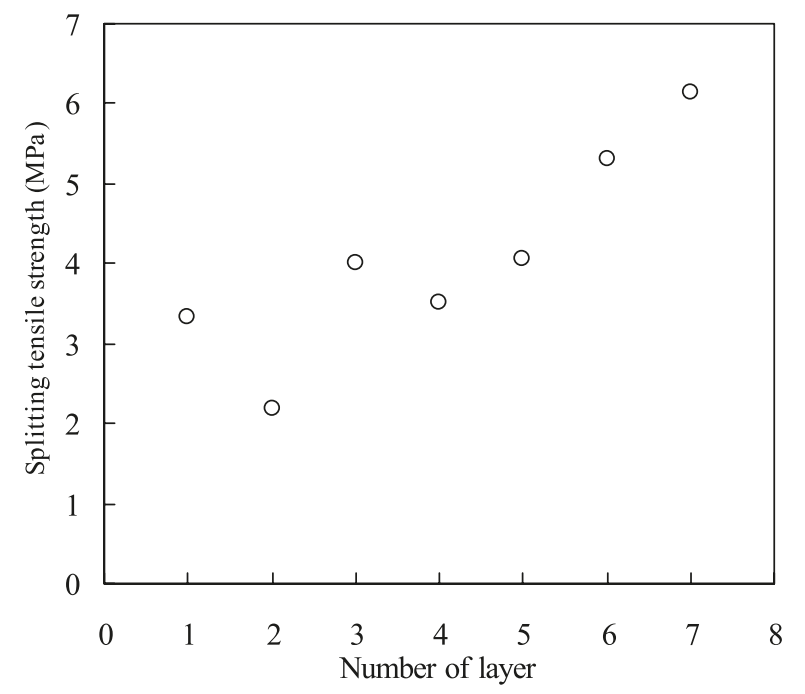

deeper. Figure 6 illustrates that BMC decreases as the layer is closer to the surface and increases as the layer lies deeper. Based on these results, deterioration of decalcified concrete slab is more severe on the surface, where calcium content is presumed to leak out and cement paste becomes porous.

Figure 7 shows the ${ }^{1} \mathrm{H}$ NMR spectrum of organic matter extracted from each layer. The figure indicates the peaks of oxyethylene group, $\left(\mathrm{O}-\mathrm{CH}_{2} \mathrm{CH}_{2}\right)_{n}$, of windshield washer fluid at around 3.5-4.4 ppm in each layer (Moriyoshi et al. 2002). This means that concrete slabs are decalcified by organic matter in the air, and as decalcification progresses, tensile strength decreases. Such a phenomenon indicates that concrete begins to deteriorate at the surface by absorbing a variety of organic matter present in the air through the $8 \mathrm{~cm}$ thick asphalt layer through a process of "aspiration".

\section{Conclusion}

This study described the mechanism of concrete and limestone deterioration caused by decalcification due to certain organic matter present in the atmosphere that was absorbed 
Fig. 5. Specific surface area of cement paste for each layer of decalcified concrete slab.

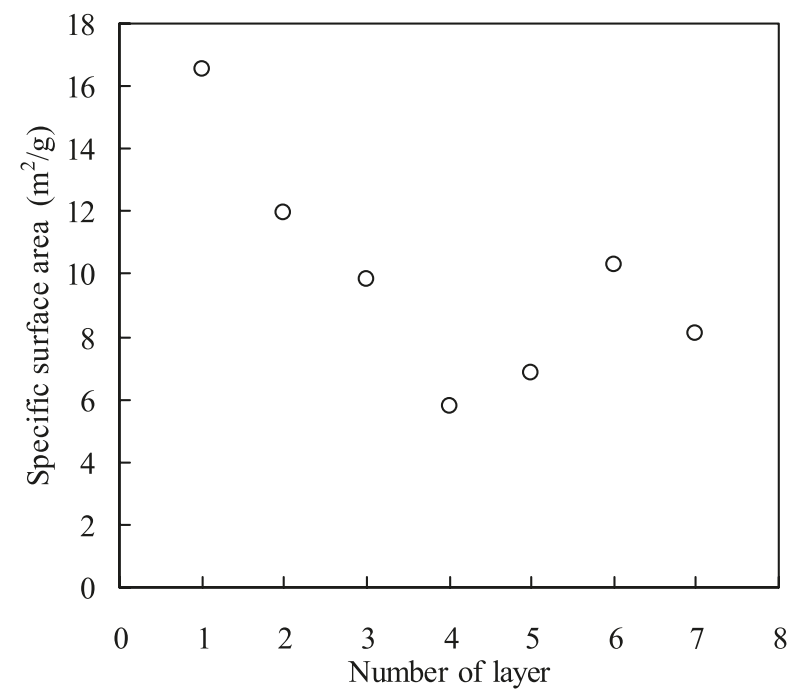

Fig. 6. Bone mineral content (BMC) of cement paste for each layer of decalcified concrete slab.

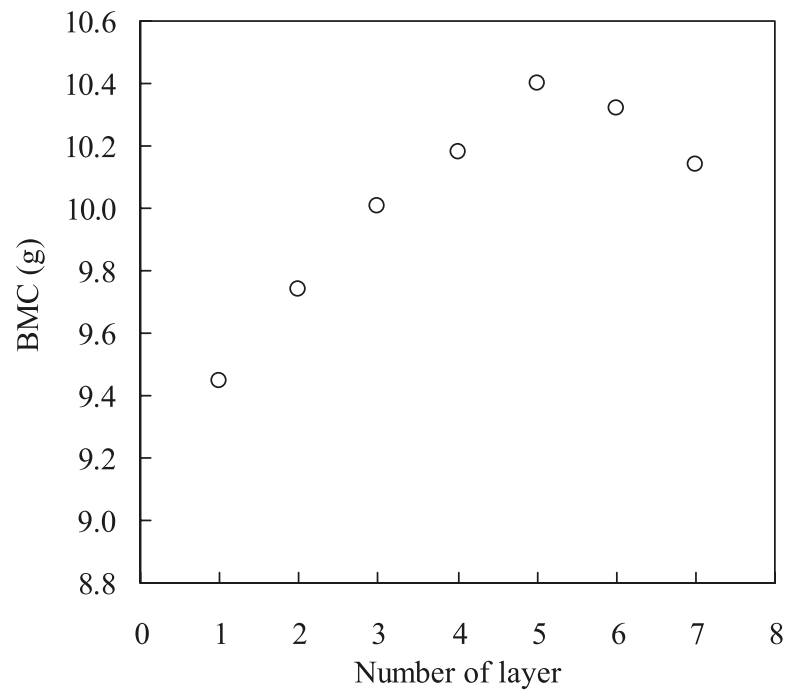

Fig. 7. The ${ }^{1} \mathrm{H}$ NMR spectrum of organic matter extracted from each layer of decalcified concrete slab.

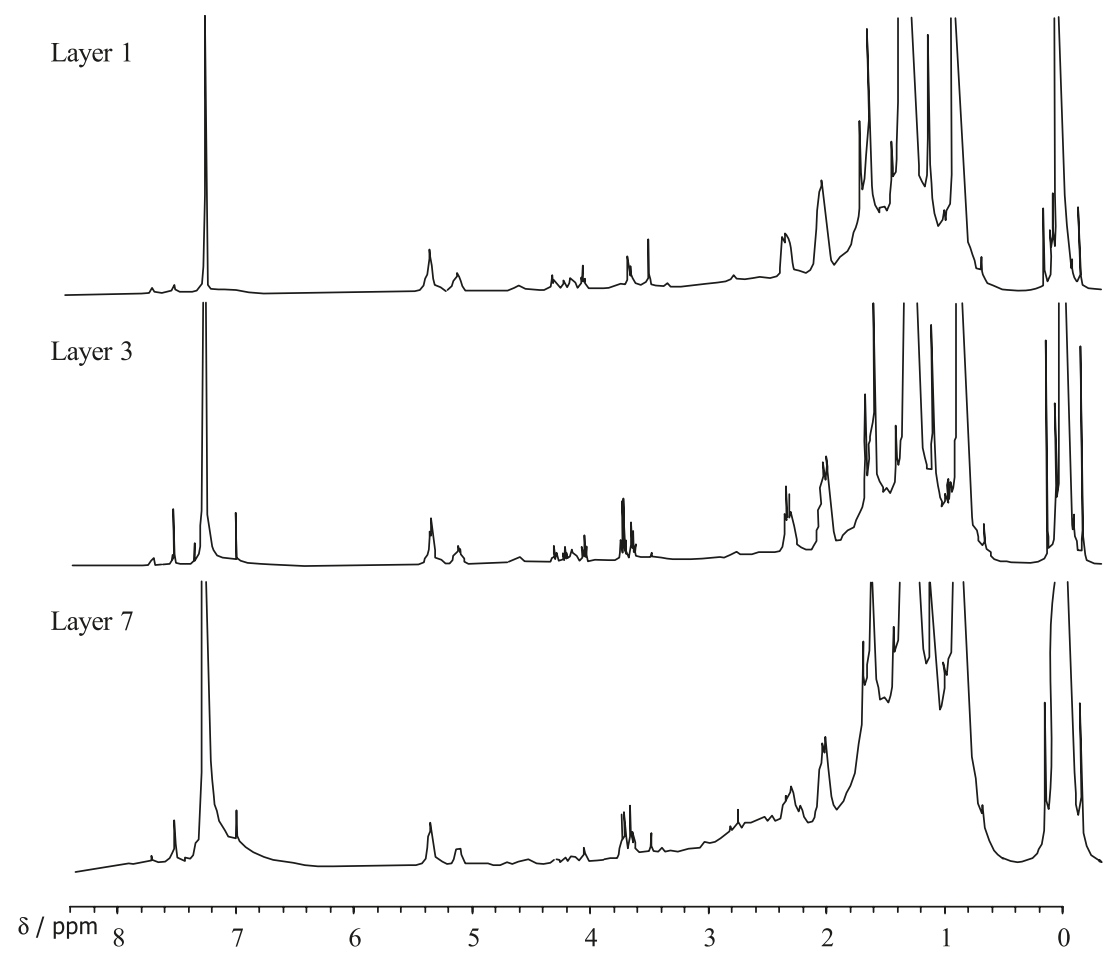

by concrete and limestone structures through a process of "aspiration" and its various adverse effects. As a result, the study found that phthalic acid esters, as specific substances with endocrine disrupting effects that have adverse effects on humans, TMPDIB, and amides also harm concrete. Based on these results, we believe there is a very high possibility that a wide range of additives - esters, surfactant and salt - that are premixed in concrete closely relate to concrete deterioration. These substances strongly warrant further research and discussion.

\section{Acknowledgments}

The authors would like to express their gratitude to Pro- fessor Yoneda, former Professor Kitagawa, and Associate Professor Tabata at Graduate School of Engineering, Hokkaido University for instrumental advice and to the Hokkaido Government for valuable samples on the implementation of this study.

\section{References}

Baer, N.S., and Snethlage, R. 1996. Saving Our Architectural Heritage. John Wiley \& Sons, New York.

Kishitani, K., Izumi, I., Nishizawa, N., Kita, T., and Maeda, T. 1990. Cement concrete structure durability series: Decalcification. Gihodo Shuppan Co., Ltd., Tokyo, Japan. [In Japanese.]

Ministry of Economy, Trade and Industry Government of Japan. 
2002. Assessment of the hazards of certain chemical substances which have been "suspected to be endocrine disrupters". Ministry of Economy, Trade and Industry Government of Japan, Tokyo, Japan. [In Japanese.]

Moriyoshi, A., Tabata, M., Kitagawa, H., Tokumitsu, K., and Saeki, N. 2002. Decalcification of cement concrete structures and dissolution of bitumen by windshield washer fluid. Journal of the Japan Petroleum Institute, 45(2): 84-88.

Reinhardt, S.K. 1997. Penetration and permeability of concrete. E \& FN SPON, London.

Sasaki, I., Moriyoshi, A., and Hachiya, Y. 2006b. Water/gas permeability of bituminous mixtures and involvement in blistering phenomenon. Journal of the Japan Petroleum Institute, 49(1): 57-64. doi:10.1627/jpi.49.57.
Sasaki, I., Moriyoshi, A., Hachiya, Y., and Nagaoka, N. $2006 a$. New test method for moisture permeation in bituminous mixtures. Journal of the Japan Petroleum Institute, 49(2): 33-37.

Sasaki, I., Moriyoshi, A., and Tsunekawa, M. 2006c. Water accumulation and behavior of surfactant associated with moisture permeation in bituminous pavement on concrete deck bridge. Journal of the Japan Petroleum Institute, 49(6): 315-320. doi:10.1627/jpi.49.315.

Yokoyama, S., Suzuki, A., Murakami, M., Ogi, T., Koguchi, K., and Nakamura, E. 1987. Liquid fuel production from sewage sludge by catalytic conversion using sodium carbonate. Fuel, 66(8): 1150-1155. doi:10.1016/0016-2361(87)90315-2. 